\title{
Cut-off Percentage of Ethanol in Diesel-Biodiesel Based Fuel Blends and Analysis of Emissions in Four Stroke-Compression Ignition Engines
}

\author{
P. Suresh Kumar*†, N. Prasanthi Kumari** and Amit Kumar Sharma*** \\ *Department of Mechanical Engineering, University of Petroleum and Energy Studies, Dehradun, India \\ **Department of Electronics and Communications Engineering, University of Petroleum and Energy Studies, Dehradun, \\ India \\ ***Department of Biofuel Research Laboratory, Centre of Alternative Energy Research, University of Petroleum and \\ Energy Studies, Dehradun, India \\ †Corresponding author: P. Suresh Kumar; psuresh@ddn.upes.ac.in
}

Nat. Env. \& Poll. Tech.

Website: www.neptjournal.com

Received: 04-08-2020

Accepted: 16-09-2020

Key Words:

Ethanol

Biodiesel

Engine performance

Emissions

DI diesel engine
Revised: $08-09-2020$

\begin{abstract}
One of the major challenging problems faced globally is energy security, and new generation researchers' emphasis is on alternative fuels, which could switch the fossil fuels products entirely or moderately. The current study focuses on the use of ethanol as an alternative fuel for internal combustion engines. The speciality of this fuel is the oxygenated short-chain alcohols. These alcohols may be made through the fermentation of biomass, hence this fuel comes under a renewable source of energy. A four-stroke, single-cylinder, water-cooled and naturally aspirated compression ignition diesel engine was selected for this research. The above engine tested fuels like diesel, blends of diesel and ethanol. Diesel (D 100) $(\mathrm{v} / \mathrm{v})$, ethanol $5 \%$ with the addition of diesel $95 \%(E 5)(v / v)$, ethanol $10 \%$ with the addition of diesel $90 \%(E 10)(v / v)$, ethanol $15 \%$ with the addition of diesel $85 \%(E 15)(v / v)$ and ethanol $20 \%$ with the addition of diesel $80 \%(E 20)(v / v)$. The influence of the upturn of ethanol in the diesel delivered a decline of nitrogen oxides (NOx), carbon monoxide (CO) and unburnt hydrocarbons (UHC) matched to diesel fuel. It concluded that in these test fuels, E15 has higher brake thermal efficiency; E20 has higher brake specific fuel consumption. For emissions, E20 is the best blend compared to the remaining test fuels.
\end{abstract}

\section{INTRODUCTION}

In the 19th century, the entire world faced fuel crises due to limited petroleum-based fuels and elevation in prices. Shipping, moving, power generation and fields of agriculture mainly use internal combustion engines only. Petroleum and diesel-based fuels increase the emissions like oxides of nitrogen, carbon monoxide, total unburnt hydrocarbons, soot and particulate matter. These emissions percentage increases in the atmosphere and results in several diseases in human, animal and plant life. Since fossil fuel engines give more emissions, the entire world is following inflexible emission regulations. The researchers are focused on finding alternative fuels for internal combustion engines (Ribeiro et al. 2007, Cheung et al. 2008). Biodiesel is a very good alternative to fossil fuels as it easily mix-up with diesel and petroleum products. Generally used biodiesels are sunflower, Karanja, polanga, neem and jatropha, etc. The aforesaid biodiesels can be directly used in internal combustion engines without any major changes in the engines. The advantage of using these biodiesels is reducing the emissions and greenhouse gas discharges, and increase the world farm market with village development (Agarwal 2007). With new technologies ethanol is produced from corn, leftover biomass constituents, barely, molasses and cane (De Caro et al. 2001, Kremer \& Fachetti 1965). Additives are added to internal combustion biodiesel engines to improve the mixing properties, reduce the ignition delay and lubricity. The main additives for biodiesel based internal combustion are oxygenates. The advantage of these oxygenate additives is that they improve the cetane number, improves efficiency, reduction of emissions, particulate matter and reduce the knocking. Generally used oxygenates are butanol, ethanol, pentanol and propanol. One of the analysis (Kumar et al. 2013) stated that by using a three-way catalytic converter system almost all the exhaust gases such as nitrogen oxides, unburnt hydrocarbons and carbon monoxide are reduced. Exhaust emission analysis was carried out by different methods such as catalytic converters, exhaust gas recirculation (Kumar et al. 2020, 2013, 2012). Ethanol physicochemical properties are not suitable as a direct fuel. It has low density, viscosity and cetane number. The acceptable diesel and ethanol blend ratio is $20 \%$ that means without major changes in the diesel engine, it can operate with all loads. 
Another way of reducing emissions in internal combustion engines is using burnt petro-diesel fuels. The main raw materials used for producing ethanol are corn, barley, sugar cane and sugar beets, etc. Ethanol has a high-octane rating and low emission characteristics; its pros and cons clearly explained in the studies by (Schuetzle et al. 2002, Wugao $\&$ Zhen 2002). The oxygen percentage in ethanol is $34.73 \%$ by mass that enhances the combustion in diesel engines in the test fuel blends. The reduction of emissions of total unburnt hydrocarbons and conversion of carbon monoxide to carbon dioxide due to extra atom of oxygen in ethanol-diesel test fuel blends; even if numerous theories show that NOx emissions are reduced due to increased ethanol percentage in the diesel-ethanol blends (Khan et al. 2018).

Ethanol is directly not used as a primary fuel, but blending with diesel can be used in diesel engines and also used in spark-ignition engines as blended fuel. Sophisticated engine equipment is required to operate with these test fuels (Zhang et al. 2005, Nibin et al. 2005). Kumar et al. 2014 conducted experiments on four-stroke diesel engine with different biodiesel percentages at a constant speed of $1500 \mathrm{rpm}$. At $15 \%$ of biodiesel blends, NOx emissions and smoke are reduced. The fumigation system is a major part of these types of fuels to blend the required percentage. It is observed that internal combustion engine efficiency increases and reduction of emissions taking place in a diesel-ethanol blend. While increasing the ethanol percentage in blends, the brake power, brake specific fuel consumption and brake thermal efficiency are enhanced. The engine with the new blend as test fuel is kept on running for some time until it reaches the constant speed that is $1500 \mathrm{rpm}$. Then all the readings are noted and observed at peak injection pressures with a comparative analysis between performances and exhaust emissions (Puhan et al. 2009). In a recent research, biodiesel has been used as a supplementary amphiphilic for making micelles that have non-polar end preoccupied with near diesel and glacial bounce on the way to ethanol or butanol (Fernando \& Hanna 2004). Another separate study reports the compression ignition engines with diesel and biodiesel as test fuels; the efficiency and pollution discharge depend on the fuel nozzle opening pressure, valve timing for injection and compression ratio (Kumar et al. 2012). In this study, ethanol percentage is increased up to $20 \%$ with an increment of $5 \%$ and compared with all the ethanol-blended fuels with diesel. Also, this paper establishes a better blending percentage of ethanol with diesel for compression ignition engines.

\section{MATERIALS AND EXPERIMENTAL SET-UP}

\section{Preparation of Test Fuel}

Initially, the test fuel prepared for running the diesel engine included diesel $95 \%$ with ethanol 5\% (E 5), diesel 90\% with ethanol $10 \%$ (E10), diesel $85 \%$ with ethanol $15 \%$ (E 15 ) and diesel $80 \%$ with ethanol $20 \%$ (E20). Ethanol and diesel were purchased from the market and test fuels were prepared as the above-mentioned percentages in the chemistry lab. The test fuel properties of all the fuels are listed in Table 1. Digital bomb calorimeter was used for measuring the calorific value of test fuels and viscometers for measuring kinematic viscosity.

Table 2 comprises the properties of test fuels. For experimental analysis ethanol mixed with diesel in different varying proportions like 5\% ethanol and 95\% diesel, 10\% ethanol and $90 \%$ diesel, $15 \%$ ethanol and $85 \%$ diesel, and $20 \%$ ethanol and $80 \%$ diesel by volume respectively.

\section{Experimental Test Rig}

Fig. 1 shows the diesel engine test rig. It is a water-cooled, natural aspirated, four-stroke single-cylinder computerized engine. Full details and specification of the engine are incorporated in Table 3.

\section{Experimental Procedure}

The engine was operated with pure diesel as basic and

Table 1: Properties of diesel and ethanol fuel (Pinzi et al. 2017).

\begin{tabular}{|c|c|c|}
\hline Properties &  & $\begin{array}{l}\text { Ethanol } \\
\mathrm{C}_{2} \mathrm{H}_{5} \mathrm{OH}\end{array}$ \\
\hline Calorific value $\mathrm{kJ} / \mathrm{kg}$ & 42510 & 26800 \\
\hline Cetane Number & 50 & 8 \\
\hline Density, $\mathrm{kg} / \mathrm{m}^{3}$ at $20^{\circ} \mathrm{C}$ & 842.4 & 788 \\
\hline $\begin{array}{l}\text { Kinematic viscosity, } \times 10^{-2} \\
\mathrm{~m}^{2} / \mathrm{s} \text { at } 20^{\circ} \mathrm{C}\end{array}$ & 2.8 & 1.2 \\
\hline $\begin{array}{l}\text { Latent heat of evaporation, } \\
(\mathrm{kJ} / \mathrm{kg})\end{array}$ & 252 & 840 \\
\hline Flash point $\left({ }^{\circ} \mathrm{C}\right)$ & 79 & 13.5 \\
\hline $\begin{array}{l}\text { Auto ignition temperature } \\
\left({ }^{\circ} \mathrm{C}\right)\end{array}$ & 251 & 420 \\
\hline Oxygen content (wt \%) & 0 & 34.8 \\
\hline
\end{tabular}

Table 2: Properties of test fuel (Kirankumar et al. 2015)

\begin{tabular}{|lll|}
\hline Test Fuel & $\begin{array}{l}\text { HHV-Higher Heating Value } \\
(\mathrm{MJ} / \mathrm{kg})\end{array}$ & $\begin{array}{l}\text { Density at } 15^{\circ} \mathrm{C}, 1 \mathrm{bar} \\
\left(\mathrm{kg} / \mathrm{m}^{3}\right)\end{array}$ \\
\hline Diesel & 43.4 & 846 \\
E20 & 39.01 & 821 \\
E15 & 40.35 & 827 \\
E10 & 41.22 & 831 \\
E5 & 42.08 & 834 \\
\hline
\end{tabular}


Table 3: Engine specifications.

\begin{tabular}{|lll|}
\hline S. No. & Particulars & Specifications \\
\hline 1 & Make & $\begin{array}{l}\text { Field marshal Diesel } \\
\text { engines }\end{array}$ \\
2 & Rated Brake Power $(\mathrm{BHP} / \mathrm{kW})$ & $10 / 7.35110$ \\
3 & Rated speed (rpm) & 1500 \\
4 & Number of cylinders & One \\
5 & Bore x Stroke (mm) & $120 \mathrm{x} 139.7$ \\
6 & Compression ratio & $17: 1$ \\
7 & Cooling System & Water Cooled \\
8 & Lubrication System & Forced Feed \\
9 & Cubic Capacity & $1580 \mathrm{cc}$ \\
10 & Specific Fuel Consumption & $265 \mathrm{~kW}$ hr OR $195 \mathrm{~g} /$ \\
& & bhp/hr \\
\hline
\end{tabular}



Fig. 1: Photograph of diesel engine test rig.

reference fuel for estimating the brake power, brake specific fuel consumption and exhaust gas analysis of other test fuels. For the experimental process with all diesel and ethanol blends, an individual fuel experiment was run for apiece test fuel event, the test rig as shown in Fig. 1. For tests, four different loads $25 \%, 50 \%, 75 \%$ and $100 \%$ were considered. While testing engine speed, $1000 \mathrm{rpm}$ and compression ratio 17:1 was preserved. The cooling water flowing inside the engine jackets and calorimeter was attuned at $63^{\circ} \mathrm{C}$. The diesel engine test rig was on the go and endorsed to track for 15-20 minutes to go on steady mode. The diesel machine functional constraints such as brake power or brake thermal efficiency and brake specific fuel consumption were noted for further calculations. By using AVL gas analyser for exhaust gases like unburnt hydrocarbons, oxides of nitrogen, carbon dioxide and carbon monoxide were also noted.

\section{RESULTS AND DISCUSSION}

\section{Performance Assessment}

In this paper performance analysis was studied by the parameters such as brake thermal efficiency and brake specific fuel consumption. BTE and BSFC against different loads were compared for diesel and ethanol blends of
$5 \%, 10 \%, 15 \%$ and $20 \%$, i.e. E-5, E-10, E-15 and E-20 respectively. BTE is more in diesel compared with other test fuels. BTE is lower at lower loads for all test fuels and increases with increasing the load because the combustion of fuel is more and hence increase in heat energy follows the increasing of brake thermal efficiency. BSFC is low in diesel compared with other blended test fuels. BSFC is higher at lower loads for all test fuels and it decreases with an increase in load for all test fuels. As the load increases, the fuel rate also increases, which means the fuel combustion completed in less time. Hence, as the load increases, the brake specific fuel consumption decreases for all test and blended fuels.

Brake thermal efficiency: Fig. 2 explains that the brake thermal efficiency (BTE) is one of the most significant engine's performance parameters and indicates how efficiently fuel burnt during combustion can be converted into useful work. The variation of brake thermal efficiency with load for diesel, biodiesel and its ethanol blends (D100, E-5, E-10, E-15 and E20) is shown in Fig. 2. It is observed that the brake thermal efficiency of diesel biodiesel and ethanol blends increased with increasing load for all type of fuel blends. The brake thermal efficiency of E-20 was $22.6 \%$, $28.1 \%, 30.9 \%$ and $32.9 \%$ at $25 \%, 50 \%, 75 \%$ and $100 \%$ load respectively. Furthermore, the BTE of CI engine was found to decrease with the increasing share of ethanol. The BTE of diesel engine was analysed as 34\%, 33.6\%, 33.2\% and $32.9 \%$ for E-5, E-10, E-15 and E-20 respectively, which is lower than D100 fuel (34.5\%). This is due to combined effect of low caloric value blends, which are accountable for spray characteristics leading to inferior air-fuel mixture formation and combustion resulting in lower brake thermal efficiency.

Brake specific fuel consumption: The brake specific fuel consumption indicates the quantity of fuel supplied to the engine per unit of power production. The variation of BSFC of different diesel ethanol and biodiesel blends (E5, E-10, E15 and E-20) at different load is shown in Fig. 3

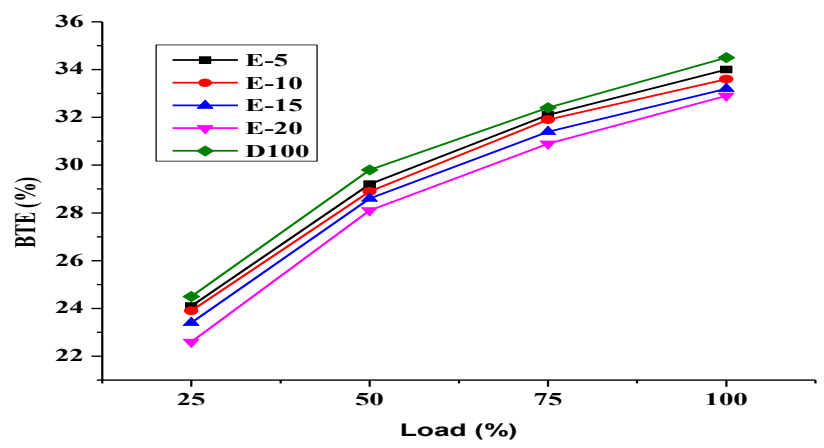

Fig. 2: BTE variation with load for D100, E-5, E-10, E-15 and E-20 at $1500 \mathrm{rpm}$. 


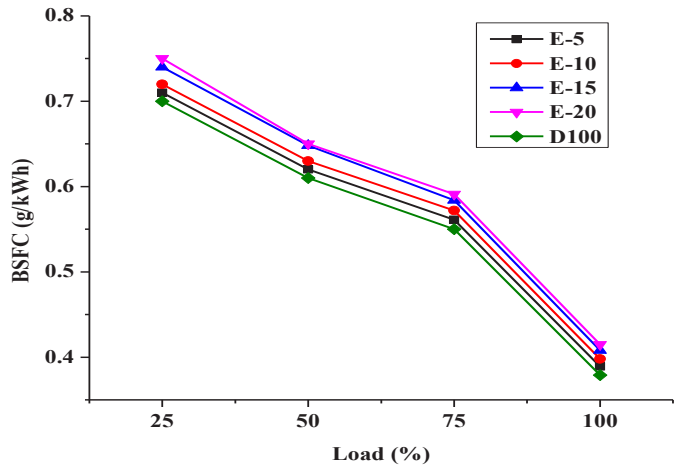

Fig. 3: BSFC variation with load for D100, E-5, E-10, E-15 and E-20 at $1500 \mathrm{rpm}$.

compared with base fuel, i.e. diesel. The results revealed that BSFC increased with the increasing amount of ethanol in fuel blends. Maximum BSFC was observed for E-20 $(0.415 \mathrm{~kW} / \mathrm{h})$ in comparison to E-5 $(0.389 \mathrm{~kW} / \mathrm{h}), \mathrm{E}-10$ $(0.398 \mathrm{~kW} / \mathrm{h})$, E-15(0.408 kW/h) and D100 (0.379 kW/h) at $100 \%$ load. Similarly, the BSFC of the engine was found to be increasing with increasing load. These data attributed in line with reported literature. The reason behind this may be a lower calorific value of fuel blends as calorific value decrease with the increasing share of ethanol.

\section{Exhaust Emission Assessment}

Exhaust gas analyser was used for the analysis of exhaust emissions for this study. The main polluted exhaust gas emissions are carbon monoxide (CO), carbon dioxide $\left(\mathrm{CO}_{2}\right)$, unburnt hydrocarbons (UHC) and nitrogen oxides (NOx) that are taken into account for exhaust gas emission analysis. These exhaust emissions are compared with diesel fuel to other test fuels. The observations made in this exhaust analysis was that the diesel fuel has a higher value of exhaust emissions compared to the other test fuels. E 20 has lower exhaust gas emission values compared to other test fuels and E 20 has a lower value of adiabatic flame temperature and the most homogenous fuel with respect to other test fuels. The cut off ratio of ethanol and diesel is $20 \%$ that means diesel $80 \%$ and ethanol $20 \%$ gives the best results when compared to other ethanol blended test fuels.

Carbon monoxide: The effect of engine load on $\mathrm{CO}$ emissions is shown in Fig. 4. The results revealed that with increasing load, $\mathrm{CO}$ emissions decreased because the combustion is more complete as the load increases. Furthermore, $\mathrm{CO}$ emissions also decreased with the increasing share of ethanol in fuel blends, e.g. the $\mathrm{CO}$ emissions for $\mathrm{E} 5, \mathrm{E} 10, \mathrm{E} 15$ and $\mathrm{E} 20$ was $2.32 \%, 2.27 \%, 2.22 \%$ and $2.18 \%$ respectively at $100 \%$ load in comparison to diesel (2.36\%). This may be due to the reason that the increasing share of

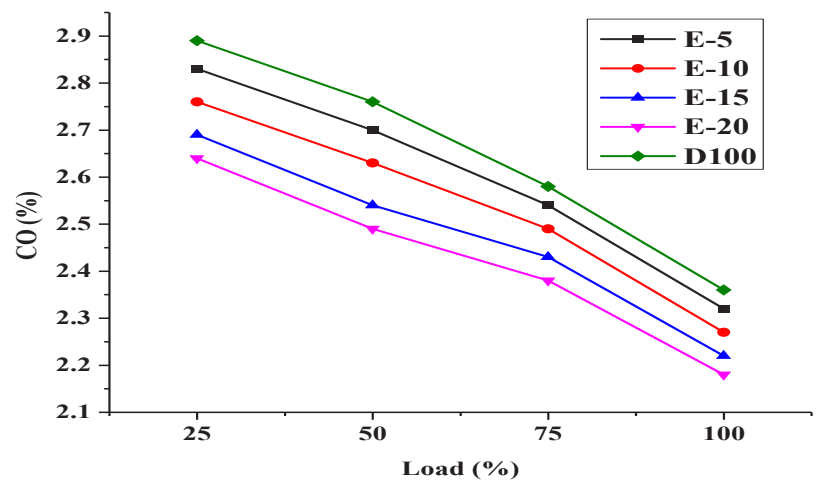

Fig. 4: CO variation with load for D100, E-5, E-10, E-15 and E-20 at $1500 \mathrm{rpm}$.

ethanol results in higher oxygen in fuel blends which leads to complete combustion.

Carbon dioxide: The variation of $\mathrm{CO}_{2}$ with increasing load as shown in Fig. 5. It is observed from the figure that the emission of carbon dioxide increases with increasing load. This is vice versa of $\mathrm{CO}$ emissions and indicates that combustion improved with increasing load. Moreover, the emission of carbon dioxide decreased with the increasing share of ethanol in fuel blends. The emission of $\mathrm{CO}_{2}$ was observed as $3.31 \%, 3.2 \%, 3.1 \%, 2.99 \%$ and $3.4 \%$ for E-5, E-10, E-15 and E-20 respectively at $100 \%$ load which was lower than diesel (3.4\%). This may be due to the reason that the oxygenated fuels result in slightly less $\mathrm{CO}_{2}$ emission as the biodiesel has less carbon in its molecules and the combustion of ethanol products contain less $\mathrm{CO}_{2}$ and more $\mathrm{H}_{2} \mathrm{O}$.

Nitrogen oxide: The variation of NOx emissions with diesel-ethanol blends is shown in Fig. 6. The results revealed that with increasing load, NOx emission also increased. NOx emissions increase in all cases as the load increases due to higher combustion temperature. In the case of biodiesel-diesel-ethanol blends, ethanol addition reduces NOx emissions as compared to diesel fuel. The NOx emissions

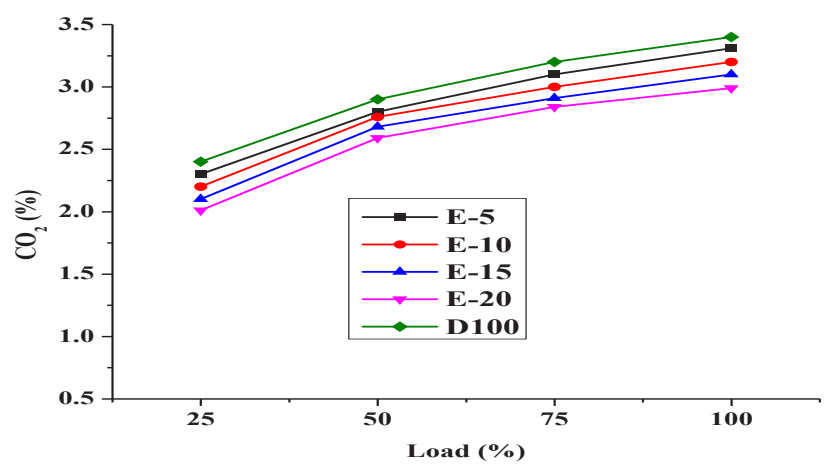

Fig. 5: $\mathrm{CO}_{2}$ variation with load for D100, E-5, E-10, E-15 and E-20 at $1500 \mathrm{rpm}$. 


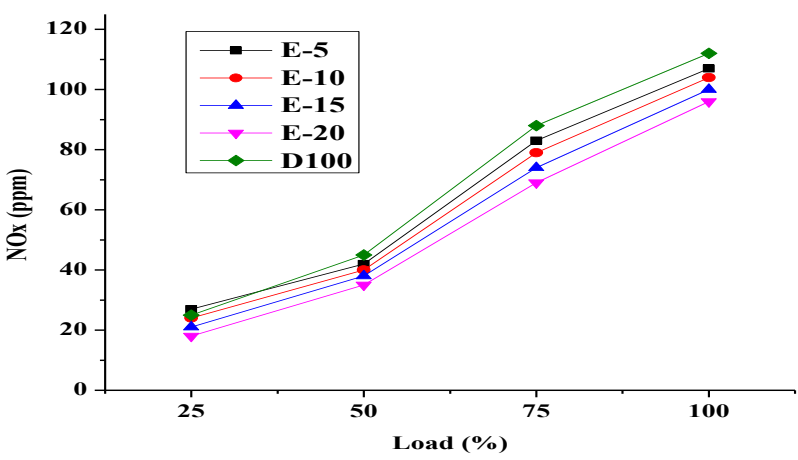

Fig. 6: $\mathrm{NO}_{\mathrm{X}}$ variation with load for D100, E-5, E-10, E-15 and E-20 at $1500 \mathrm{rpm}$.

of E-5, E-10, E-15 and E-20 are 107 ppm, 104 ppm, 100 $\mathrm{ppm}$, and $96 \mathrm{ppm}$ in comparison to diesel (112 ppm). This might be because of the cooling effect of ethanol leading to lower cylinder combustion temperatures where NOx is formed, despite the previously noted higher exhaust temperature at low load, but does not contribute to NOx production there because of lower exhaust temperatures than in-cylinder temperatures.

Unburnt hydrocarbons: The effect of diesel-ethanol biodiesel blends on unburn hydrocarbon emissions with the variation of load as shown in Fig. 7. The results showed that unburn hydrocarbons decreased with increasing load. Unburnt hydrocarbons are the results of incomplete combustion. As the load increases, more complete combustion is achieved and less UHC is generated. In addition, UHC emissions decreased with the increasing amount of ethanol in fuel blends. The UHC emissions of E-5, E-10, E-15 and E-20 are 12.9 ppm, 12.6 ppm, $12.2 \mathrm{ppm}$ and $11.9 \mathrm{ppm}$ respectively, which was lower than diesel (13.5 ppm). This may be due to the presence of more oxygenated fuel which leads to complete combustion.

\section{CONCLUSIONS}

The present investigation was carried out on a single-cylinder, four strokes, naturally aspirated, water-cooled and compression ignition diesel engine at a constant speed of $1500 \mathrm{rpm}$.

Brake thermal efficiency was more in diesel fuel compared to ethanol diesel blended fuels. E20 has lower BTE with respect to all other fuel samples.

Brake specific fuel consumption was the least in diesel fuel compared to other test fuels. E20 has higher BSFC with respect to all other blend fuels.

The exhaust emissions such as carbon monoxide, carbon dioxide, unburnt hydrocarbons and nitrogen oxides for E-20 blend was least compared to all other test fuels.

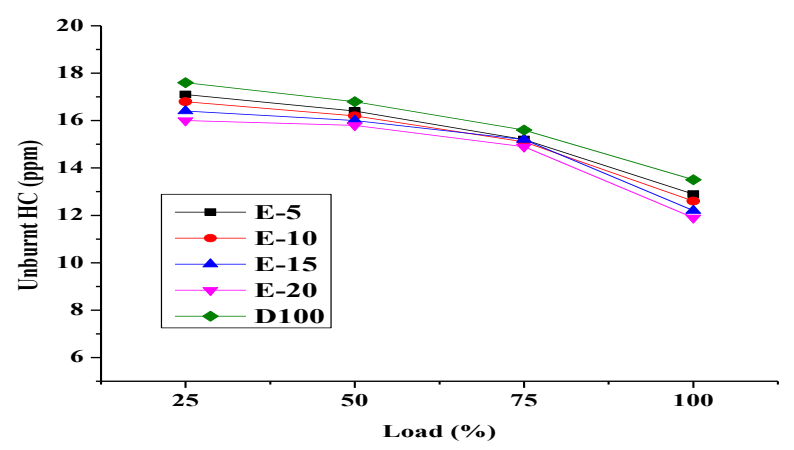

Fig. 7: Unburnt hydrocarbons variation with load for D100, E-5, E-10, E-15 and E-20 at 1500 rpm.

The above test fuels performance and emission characteristics had a noble effect on the output compared to diesel fuel and numerous experimental studies similar to and supported our present findings. Further increasing the ethanol percentage in diesel fuel, i.e. more than $25 \%$ is not suggestible because of the following reasons:

1. Increasing the percentage of ethanol in diesel increases the knocking levels.

2. Adding of ethanol content more than $20 \%$ in diesel, the negative effects will occur such as less energy content due to which the thermal efficiency decreases because of the reduced burning temperatures.

3. Using of $\mathrm{E} 20$ fuel increases the saving of petro diesel fuel reserves, hence reduces the depletion of petro diesel fuels. The production of E20 fuel increases when the international market demands then their cost may reduce drastically.

4. Confrontational effect of humankind if the higher percentage of ethanol present in diesel blends.

\section{REFERENCES}

Agarwal, A.K. 2007. Biofuels (alcohols and biodiesel) applications as fuels for internal combustion engines. Progress in Energy and Combustion Science, 33(3): 233-271.

Cheung, C.S., Cheng, C., Chan, T.L., Lee, S.C., Yao, C. and Tsang, K.S. 2008. Emissions characteristics of a diesel engine fuelled with biodiesel and fumigation methanol. Energy \& Fuels, 22(2): 906-914.

De Caro, P.S., Mouloungui, Z., Vaitilingom, G. and Berge, J.C. 2001. Interest of combining an additive with diesel-ethanol blends for use in diesel engines. Fuel, 80(4): 565-574.

Fernando, S. and Hanna, M., 2004. Development of a novel biofuel blend using ethanol- biodiesel- diesel microemulsions: EB-diesel. Energy \& Fuels, 18(6): 1695-1703.

Khan, K., Kumar, G., Sharma, A.K., Kumar, P.S., Mandal, C. and Chintala, V. 2018. Performance and emission characteristics of a diesel engine using complementary blending of castor and karanja biodiesel. Biofuels, 9(1): 53-60.

Kirankumar, S., Nagendrababu, D.R. and Apparao, D.K. 2015. Engine performance and emissions with ethanol and diesel-biodiesel blends. International Research Journal of Engineering and Rechnology, 2(5). 
Kremer, F.G. and Fachetti, A. 2000. Alcohol as automotive fuel-Brazilian experience (No. 2000-01-1965). SAE Technical Paper.

Kumar, P. Suresh, Bhatnagar, Aditya, Kumari, N. Prasanthi and Sahoo, P. K. 2014. Reduction of NOx emissions with three-way catalytic converter for IDI engine fuelled with diesel, JSVO and their blends. International Journal of Engineering Research \& Technology, 2(2): 1-11.

Kumar, P.S., Antony, F. and Sahoo, P.K. 2013. The performance and NOx emissions of a IDI diesel engine at distinct EGR rates fuelled with JB100, JB80, JB60, JB40, JB20 and diesel. International Journal of Engineering Science and Technology, 5(3): 519.

Kumar, P.S., Donga, R.K. and Sahoo, P.K. 2012. Experimental comparative study between performance and emissions of jatropha biodiesel and diesel under varying injection pressures. International Journal of Engineering Sciences \& Emerging Technologies, 3(1): 98-112.

Kumar, P.S., Donga, R.K. and Sahoo, P.K. 2012. Experimental comparative study between performance and emissions of jatropha biodiesel and diesel under varying injection pressures. International Journal of Engineering Sciences \& Emerging Technologies, 3(1): 98-112.

Kumar, P.S., Joshi, S., Prasanthi Kumari, N., Sharma, A., Nair, S. and Chatterjee, S. 2020. Reduction of emissions in a biodieseldfueled compression ignition engine using exhaust gas recirculation and selective catalytic reduction techniques. Heat Transfer, 49(5): 3119-3133.

Nibin, T., Sathiyagnanam, A.P., Sivaprakasam, S. and Saravanan, C.G. 2005. Investigation on emission characteristics of a diesel engine using oxygenated fuel additive. Journal of the Institution of Engineers(India), Part MC, Mechanical Engineering Division, 86: 51-54.
Pinzi, S., Redel-Macías, M.D., Leiva-Candia, D.E., Soriano, J.A. and Dorado, M.P. 2017. Influence of ethanol/diesel fuel and propanol/ diesel fuel blends over exhaust and noise emissions. Energy Procedia, 142: 849-854.

Puhan, S., Jegan, R., Balasubbramanian, K. and Nagarajan, G., 2009. Effect of injection pressure on performance, emission and combustion characteristics of high linolenic linseed oil methyl ester in a DI diesel engine. Renewable Energy, 34(5): 1227-1233.

Ribeiro, N.M., Pinto, A.C., Quintella, C.M., da Rocha, G.O., Teixeira, L.S., Guarieiro, L.L., do Carmo Rangel, M., Veloso, M.C., Rezende, M.J., Serpa da Cruz, R. and de Oliveira, A.M. 2007. The role of additives for diesel and diesel blended (ethanol or biodiesel) fuels: A review. Energy \& fuels, 21(4): 2433-2445.

Schuetzle, D., Han, W., Srithammavong, P., Akarapanjavit, N., Norbeck, J.M. and Corkwell, K., 2002. The evaluation of diesel/ethanol blends for diesel vehicles in Thailand: Performance and emissions studies. In: Proceedings of the 14th International Symposium on Alcohol (ISAF), pp. 12-15.

Wugao, Z. and Zhen, H. 2002, November. Study of performance and exhaust emission of a compression ignition diesel engine fueled with bio-diesel. In: Proceedings of the 14th International Symposium on Alcohol (ISAF).

Zhang, G.D., Liu, H., Xia, X.X., Zhang, W.G. and Fang, J.H. 2005. Effects of dimethyl carbonate fuel additive on diesel engine performances. Proceedings of the Institution of Mechanical Engineers, Part D: Journal of Automobile Engineering, 219(7): 897-903. 